\title{
The new insights into cadmium sensing
}

\section{Jagna Chmielowska-Bąk, Jarosław Gzyl, Renata Rucińska-Sobkowiak, Magdalena Arasimowicz-Jelonek and Joanna Deckert*}

Department of Plant Ecophysiology, Faculty of Biology, Institute of Experimental Biology, Adam Mickiewicz University, Poznań, Poland

\section{Edited by:}

Luisa M. Sandalio, Consejo Superior de Investigaciones Científicas, Spain

\section{Reviewed by:}

Mee-Len Chye, The University of

Hong Kong, Hong Kong

Nathalie Verbruggen, Université

Libre de Bruxelles, Belgium

Luisa M. Sandalio, Consejo Superior

de Investigaciones Científicas, Spain

*Correspondence:

Joanna Deckert, Department of

Plant Ecophysiology, Faculty of

Biology, Institute of Experimental

Biology, Adam Mickiewicz

University, ul.Umultowska 89,

Poznań 61-614, Poland

e-mail: joanna.deckert@amu.edu.pl
Cadmium ( $\mathrm{Cd}$ ) is non-essential heavy metal, which in excess, exhibits deleterious effects to the most of the organisms. Mobilization of defense mechanisms against this toxic agent requires rapid activation of signaling pathways. The article presents recent advances in the research concerning cadmium signal transduction in plants. New insights into the involvement of reactive oxygen species (ROS), nitric oxide (NO), plant growth regulators, and $\mathrm{Cd}$-induced protein modifications are reviewed. Moreover, the role of recently recognized $\mathrm{Cd}$-associated signal elements, including micro RNAs and several cis- and trans-acting elements is discussed.

Keywords: cadmium, plant signaling, reactive oxygen species, nitric oxide, plant hormones, transcription factors, micro RNA

\section{INTRODUCTION}

Contamination of the environment with heavy metals, including cadmium, is a serious problem of the modern world. It is estimated that annually around 30,000 tones of cadmium are released into the environment, of which 13,000 tones result from human activity (Gallego et al., 2012). As sedentary organisms, plants cannot move actively from a contaminated environment. Therefore, their only chance to survive unfavorable conditions is the mobilization of defense mechanisms, which requires the activation of a complex signaling network. The first barriers to the most of the stress factors are cell walls and cell membrane. Numerous studies indicate that cadmium causes stimulation of membrane-localized NADPH oxidase and, in consequence, augmentation of ROS production (Olmos et al., 2003; Garnier et al., 2006; Maksymiec and Krupa, 2006; Rodríguez-Serrano et al., 2006, 2009; Yakimova et al., 2006; Hsu and Kao, 2007; OrtegaVillasante et al., 2007; Yeh et al., 2007; Heyno et al., 2008; De Michele et al., 2009; Arasimowicz-Jelonek et al., 2012). Early reaction to this heavy metal also includes the accumulation of other signaling molecules, namely calcium ions (Garnier et al., 2006; Yeh et al., 2007) and nitric oxide (NO) (Besson-Bard and Wendehenne, 2009; Mahmood et al., 2009; Arasimowicz-Jelonek et al., 2012). The cadmium signal might also be transmitted by polyamines and plant hormones such as ethylene, auxins, and jasmonic (JA), salicylic (SA), and abscisic acid (ABA) (RodríguezSerrano et al., 2006; Yakimova et al., 2006; Al-Hakimi, 2007; Maksymiec, 2011; Wen et al., 2011; Kumar et al., 2012; Masood et al., 2012; Stroiński et al., 2013). Within the cytoplasm, response to this heavy metal is, at least in part, mediated by mitogenactivated protein kinases (MAPKs), which are stimulated by $\mathrm{Cd}$ on the transcriptional and post-translation levels (Agrawal et al., 2002, 2003; Kim et al., 2003; Jonak et al., 2004; Liu et al., 2010; Chmielowska-Bąk et al., 2013b; Ye et al., 2013). The last stages of the signal transduction pathways include the regulation of genes expression. Several studies report that this heavy metal modulates the expression of transcription factors (TFs) belonging to the MYB, HSF, bZIP, WRKY, and DREB families (Suzuki et al., 2001; Yanhui et al., 2006; Ogawa et al., 2009; Shim et al., 2009; Farinati et al., 2010; Wang et al., 2010). In the past few years, significant progress has been made in understanding the cross talk between these elements and their role in the transduction of the cadmium signal. The present review focuses on the latest insights into the role of reactive oxygen species (ROS), nitrogen oxide, and hormones in plant response to this heavy metal. The most recent findings concerning $\mathrm{Cd}$-dependent regulation of genes expression are also discussed.

\section{REACTIVE OXYGEN SPECIES}

ROS are regarded as molecules causing damage to cells as well as ubiquitous signaling molecules participating in the recognition of and response to stress factors (Wrzaczek et al., 2013). It has often been postulated that ROS themselves are signal molecules. It seems that among various $\mathrm{ROS}$, hydrogen peroxide $\left(\mathrm{H}_{2} \mathrm{O}_{2}\right)$ acts as the primary messenger, in part because of its relative stability and in part because it can cross membranes through aquaporins (Møller and Sweetlove, 2010).

Reactive oxygen species, including hydrogen peroxide, seem to be important players in plants response to cadmium (Table 1). An abundance of published data indicate that $\mathrm{Cd}$ can promote the generation of $\mathrm{H}_{2} \mathrm{O}_{2}$ in both plants and plant cell cultures (Olmos et al., 2003; Garnier et al., 2006; Maksymiec and Krupa, 2006; Rodríguez-Serrano et al., 2006, 2009; Yakimova et al., 2006; Hsu and Kao, 2007; De Michele et al., 2009; Lehotai et al., 2011; Vestena et al., 2011; Arasimowicz-Jelonek et al., 2012; Zhao et al., 2012). Cd-induced $\mathrm{H}_{2} \mathrm{O}_{2}$ might be produced by plasma membrane NADPH oxidase or originate in mitochondria 
as well as in peroxisomes and then diffuse to other parts of cells and to the apoplastic space (Romero-Puertas et al., 1999, 2004; Olmos et al., 2003; Garnier et al., 2006; Maksymiec and Krupa, 2006; Rodríguez-Serrano et al., 2006, 2009; Yakimova et al., 2006; Hsu and Kao, 2007; Ortega-Villasante et al., 2007; Yeh et al., 2007; Heyno et al., 2008; De Michele et al., 2009;
Arasimowicz-Jelonek et al., 2012). It has been reported that extracellular NADPH oxidase-dependent generation of $\mathrm{H}_{2} \mathrm{O}_{2}$ may be followed by increased production of superoxide anion $\left(\mathrm{O}_{2} \bullet-\right)$ in mitochondria, which in turn, causes fatty acid hydroperoxide accumulation (Garnier et al., 2006). NADPH oxidase generates superoxide by transferring electrons from

Table 1 | Summary of Cd-induced signaling events mediated by reactive oxygen species (ROS) in different plant species.

\begin{tabular}{|c|c|c|c|}
\hline $\begin{array}{l}\text { Plant species } \\
\text { (References) }\end{array}$ & $\begin{array}{l}\text { Cd } \\
\text { concentration }\end{array}$ & Time of treatment & Signaling events \\
\hline $\begin{array}{l}\text { Nicotiana tabacum (cell suspension) } \\
\text { (Olmos et al., 2003) }\end{array}$ & $5 \mathrm{mM} \mathrm{CdCl}_{2}$ & $15 \mathrm{~min}$ & $\begin{array}{l}\text { Oxidative burst mediated by } \mathrm{Ca}^{2+} \text {, calmodulin and protein } \\
\text { phosphorylation }\end{array}$ \\
\hline $\begin{array}{l}\text { Pisum sativum } \\
\text { (Rodríguez-Serrano et al., 2006, 2009) }\end{array}$ & $50 \mu \mathrm{M} \mathrm{CdCl}_{2}$ & 15 days & $\begin{array}{l}\text { Accumulation of } \mathrm{O}_{2} \bullet-\text { and } \mathrm{H}_{2} \mathrm{O}_{2}, \mathrm{Ca}^{2+} \text {-dependent } \\
\text { decrease in } \mathrm{NO} \text { levels, activation of peroxidases and } \\
\text { NADPH oxidase }\end{array}$ \\
\hline
\end{tabular}

\begin{tabular}{|c|c|c|c|}
\hline $\begin{array}{l}\text { Arabidopsis thaliana } \\
\text { (Maksymiec and Krupa, 2006) }\end{array}$ & $100 \mu \mathrm{M} \mathrm{CdSO}_{4}$ & $15 \mathrm{~h}$ & $\begin{array}{l}\text { Strong, transient } \mathrm{O}_{2} \bullet-\text { and } \mathrm{H}_{2} \mathrm{O}_{2} \text { accumulation con } \\
\text { with changes in the activity of } \mathrm{NADPH} \text { oxidase and } \\
\text { superoxide dismutase }\end{array}$ \\
\hline
\end{tabular}

Nicotiana tabacum (cell suspension) $\quad 3 \mathrm{mM} \mathrm{CdCl}_{2} \quad 8 \mathrm{~h} \quad$ Three waves of oxidative stress:

(Garnier et al., 2006)
(1) transient, NADPH oxidase-dependent accumulation of $\mathrm{H}_{2} \mathrm{O}_{2}$
(2) increased production of $\mathrm{O}_{2} \bullet-$ in mitochondria
(3) fatty acid hydroperoxide accumulation concomitant with necrotic type of cell death
Regulation of NADPH oxidase activity involving $\mathrm{Ca}^{2+}$-mediated signaling and protein phosphorylation

\begin{tabular}{|c|c|c|c|}
\hline $\begin{array}{l}\text { Lycopersicon esculentum (cell suspension) } \\
\text { (Yakimova et al., 2006) }\end{array}$ & $100 \mu \mathrm{M} \mathrm{CdSO}_{4}$ & $24 \mathrm{~h}$ & $\begin{array}{l}\text { Programmed cell death mediated by caspases and } \\
\text { accompanied by transient, NADPH-oxidase dependent } \\
\mathrm{H}_{2} \mathrm{O}_{2} \text { accumulation } \\
\text { ROS production involving NADPH-oxidase activity as well as } \\
\text { phospholipase } \mathrm{C} \text { and phospholipase D signaling pathways }\end{array}$ \\
\hline $\begin{array}{l}\text { Oryza sativa } \\
\text { (Hsu and Kao, 2007) }\end{array}$ & $5 \mathrm{mM} \mathrm{CdCl}_{2}$ & $24 \mathrm{~h}$ & $\begin{array}{l}\mathrm{H}_{2} \mathrm{O}_{2} \text { accumulation dependent on NADPH-oxidase and } \\
\text { phosphatidylinositol 3-phosphate }\end{array}$ \\
\hline
\end{tabular}

Oryza sativa $\quad 100,200, \quad 1 \mathrm{~h}$

(Yeh et al., 2007) $\quad 400 \mathrm{mM} \mathrm{CdCl}_{2}$

h Regulation of MAP kinase activity by: non-enzymatic $\left(\mathrm{OH}^{\bullet}\right)$ and enzymatic ROS production $\left(\mathrm{O}_{2} \bullet-\right.$ or $\left.\mathrm{H}_{2} \mathrm{O}_{2}\right)$ involving NADPH oxidase, CDPKs, PI3 kinase, and closing of the mitochondrial pore Regulation of NADPH oxidase and CDPKs activity by $\mathrm{Ca}^{2+}$

\begin{tabular}{|c|c|c|c|}
\hline $\begin{array}{l}\text { Arabidopsis thaliana (cell suspension) } \\
\text { (De Michele et al., 2009) }\end{array}$ & $\begin{array}{l}100,150 \mu \mathrm{M} \\
\mathrm{CdCl}_{2}\end{array}$ & 14 days & $\begin{array}{l}\text { The concomitant presence of high levels of both } \mathrm{NO} \text { and } \\
\mathrm{H}_{2} \mathrm{O}_{2} \text { triggering programmed cell death }\end{array}$ \\
\hline $\begin{array}{l}\text { Arabidopsis thaliana } \\
\text { (Liu et al., 2010) }\end{array}$ & $\begin{array}{l}1,10,50,150 \\
300 \mu \mathrm{M} \mathrm{CdCl}\end{array}$ & $12 \mathrm{~h}$ & ROS-triggered activation of MPK3 and MPK6 \\
\hline $\begin{array}{l}\text { Pisum sativum } \\
\text { (Lehotai et al., 2011) }\end{array}$ & $100 \mu \mathrm{M} \mathrm{CdCl} 2$ & $48 \mathrm{~h}$ & $\begin{array}{l}\text { Necrotic cell death associated with } \mathrm{NO} \text { and } \mathrm{H}_{2} \mathrm{O}_{2} \\
\text { generation }\end{array}$ \\
\hline $\begin{array}{l}\text { Lupinus luteus } \\
\text { (Arasimowicz-Jelonek et al., 2012) }\end{array}$ & $89 \mathrm{mM} \mathrm{CdCl} 2$ & $24 \mathrm{~h}$ & $\begin{array}{l}\text { Programmed cell death related to } \mathrm{O}_{2} \bullet-\text { and } \mathrm{NO} \text { production } \\
\text { PCD-initiated signal transduction between roots and leaves }\end{array}$ \\
\hline $\begin{array}{l}\text { Oryza sativa } \\
\text { (Zhao et al., 2012) }\end{array}$ & $\begin{array}{l}100 \mu \mathrm{M} \\
\mathrm{Cd}\left(\mathrm{NO}_{3}\right)_{2}\end{array}$ & 13 days & $\begin{array}{l}\text { Accumulation of } \mathrm{H}_{2} \mathrm{O}_{2} \text { and modification of the auxin } \\
\text { signaling pathway and/or cell-cycle gene expression }\end{array}$ \\
\hline $\begin{array}{l}\text { Glycine max } \\
\text { (Pérez-Chaca et al., 2014) }\end{array}$ & $40 \mu \mathrm{M} \mathrm{CdCl}_{2}$ & 6 days & $\begin{array}{l}\text { Antioxidative response induced by increased levels of } \mathrm{H}_{2} \mathrm{O}_{2} \\
\text { and } \mathrm{NO}\end{array}$ \\
\hline
\end{tabular}


NADPH to molecular oxygen to produce $\mathrm{O}_{2} \bullet-$, which is subsequently dismutated to $\mathrm{O}_{2}$ and $\mathrm{H}_{2} \mathrm{O}_{2}$ by superoxide dismutase enzymes (SOD). Strong superoxide accumulation (RodríguezSerrano et al., 2006, 2009; Lehotai et al., 2011; ArasimowiczJelonek et al., 2012) correlated with SOD activity (Maksymiec and Krupa, 2006) was found in plants treated with $\mathrm{Cd}$.

NADPH oxidase-dependent generation of $\mathrm{H}_{2} \mathrm{O}_{2}$ appeared to be regulated by cytosolic free calcium (Garnier et al., 2006; Yakimova et al., 2006) and ethylene (Yakimova et al., 2006). Furthermore, it has been shown that a rapid increase in cytosolic calcium levels, essential for stimulation of the NADPH oxidase, requires phospholipase $\mathrm{C}$ (PLC) activity, and most likely involves inositol-3-phosphate (IP3)-stimulated calcium channels as well as ADPribose-gated channels (Garnier et al., 2006). Apart from calcium (Rodríguez-Serrano et al., 2006, 2009), calmodulin and protein kinases play a key role in the signaling cascade that leads to a Cd-induced oxidative burst (Garnier et al., 2006). According to Yakimova et al. (2006) PLC and phospholipase D (PLD) signaling is also involved in the production of ROS. Cadmium may stimulate phospholipases and initiate further signaling through increased levels of phosphatidylinositol-triphosphate (IP3), phosphatidic acid, and cytosolic calcium (Yakimova et al., 2006). It is suggested that the downstream targets of PLC- and PLD-derived second messengers may be a variety of lipid and protein kinases, including phosphatidylinositol 3-kinase (PI-3-kinase), MAPKs, and calcium-dependent protein kinases (CDPKs) (Yakimova et al., 2006; Hsu and Kao, 2007).

The MAPK cascade is one of the important pathways involved in the transduction of external stimuli into cells. These enzymes are able to phosphorylate a wide range of substrates, including other kinases and/or TFs (Colcombet and Hirt, 2008). It has been found that two kinases, MPK3 and MPK6, exhibit much higher activity after Cd treatment. Pre-treatment with the ROS scavenger glutathione effectively inhibited their activation. These results support the hypothesis that the $\mathrm{Cd}$ sensing signaling pathway use a build-up of ROS to trigger activation of MAPKs (Liu et al., 2010). It was reported that Cd-induced activation of MAP kinases may involve not only ROS, including hydroxyl radicals $\left(\mathrm{OH}^{\bullet}\right)$, but also CDPK and PI3 kinase, and may be triggered by mitochondrial dysfunction resulting from the closure of the mitochondrial permeability transition pore (Yeh et al., 2007).

It has recently been suggested that ROS-induced signal transduction may occur by means of oxidized fragments of proteins damaged by oxidative stress. The derived peptides could act in a more a specific way, as they contain information about the organelle subjected to stressful conditions and the type of ROS produced (Møller and Sweetlove, 2010). However, in respect to cadmium, this mechanism requires further experimental research.

Hydrogen peroxide and ROS-induced secondary messengers may affect the expression of plant genes (Møller and Sweetlove, 2010). Cd-induced accumulation of $\mathrm{H}_{2} \mathrm{O}_{2}$ modifies the auxin signaling pathway, including auxin distribution (DR5-GUS), biosynthesis (OsYUCs), and transport (OsPINs), auxin-responsive (OsARFs/OsIAAs) gene expression, and/or cell division (cell-cycle genes). However, the possibility that auxin functions in parallel to $\mathrm{H}_{2} \mathrm{O}_{2}$ cannot be excluded (Zhao et al., 2012).
A growing body of evidence suggests that ROS in interaction with reactive nitrogen species (RNS) are required to induce signal transduction leading to cell death in plants exposed to $\mathrm{Cd}$ (Yakimova et al., 2006; De Michele et al., 2009; Lehotai et al., 2011; Arasimowicz-Jelonek et al., 2012). Depending on the concentration of metal in the medium, diverse forms of cell death may be observed, ranging from apoptosis to necrosis. It was found that programmed cell death (PCD) associated with increased $\mathrm{H}_{2} \mathrm{O}_{2}$ production was mediated by proteases with caspase-like activity (Yakimova et al., 2006). De Michele et al. (2009) postulated that PCD is initiated by the rapid production of phytochelatins and $\mathrm{NO}$, whereas $\mathrm{H}_{2} \mathrm{O}_{2}$ accumulation appears later on. This sequence of events actually precedes the rise of PCD in Cd-treated plants. In another model system, it was found that the generation of Cdinduced $\mathrm{H}_{2} \mathrm{O}_{2}$ was correlated with a significant increase in $\mathrm{NO}$ content. It was concluded that cell viability decreased when $\mathrm{NO}$ and $\mathrm{H}_{2} \mathrm{O}_{2}$ levels were simultaneously high in the same tissues (Lehotai et al., 2011). Arasimowicz-Jelonek et al. (2012) revealed that the generation of $\mathrm{NO}$ was accompanied by the activation of plasma membrane NADPH-oxidase and subsequent superoxide anion accumulation. The lack of simultaneous $\mathrm{H}_{2} \mathrm{O}_{2}$ accumulation during the experiment suggests that $\mathrm{O}_{2} \bullet-$ rather than $\mathrm{H}_{2} \mathrm{O}_{2}$ cooperate with NO to induce PCD. In this report, the effect of $\mathrm{Cd}$ on post-stress signaling molecules in different plant parts was investigated. When $\mathrm{Cd}$ was applied to the roots, $\mathrm{NO}$ synthesis was not accompanied by statistically significant $\mathrm{H}_{2} \mathrm{O}_{2}$ accumulation in this organ. Nevertheless, in leaves an approximately two-fold increase in $\mathrm{H}_{2} \mathrm{O}_{2}$ was concomitant with enhanced levels of NO. An accumulation of $\mathrm{NO}$ and $\mathrm{H}_{2} \mathrm{O}_{2}$ in leaves was correlated with PCD symptoms in roots, which led to the assumption that PCD initiate signal transduction between various seedling organs that induce plant defense mechanisms (Arasimowicz-Jelonek et al., 2012).

It has recently been reported (Pérez-Chaca et al., 2014) that Cd leads to a rise in $\mathrm{H}_{2} \mathrm{O}_{2}$ and $\mathrm{NO}$, and to a lesser extent $\mathrm{O}_{2} \bullet-$ content, after few hours of exposure. Accumulation of these molecules triggers the induction of antioxidative defenses, ASCGSH cycle, and NADP-dehydrogenases. A second, higher wave of $\mathrm{O}_{2} \bullet$ - production, observed after 3-day treatment, might participate in the reinforcement of antioxidant response. The described participation of reactive oxygen species in the transduction of cadmium signal and its cross talk with other signaling elements is presented in Figure 1.

\section{NITRIC OXIDE}

A growing body of evidence indicates that cadmium stress modulates NO generation in plants (Table 2). This gaseous cellsignaling molecule is involved in many plant growth and development processes, as well as in the regulation of multiple responses to biotic and abiotic stress factors. The signaling mode of NO action at the molecular level includes protein modification by binding to critical Cys residues, heme or iron-sulfur centers, and Tyr residue nitration via peroxynitrite formation $\left(\mathrm{ONOO}^{-}\right)$ (Arasimowicz-Jelonek and Floryszak-Wieczorek, 2011).

The production of NO has been demonstrated in vivo in various plant tissues exposed to Cd stress, but the time and intensity of NO generation seems to be strictly dependent on the form 


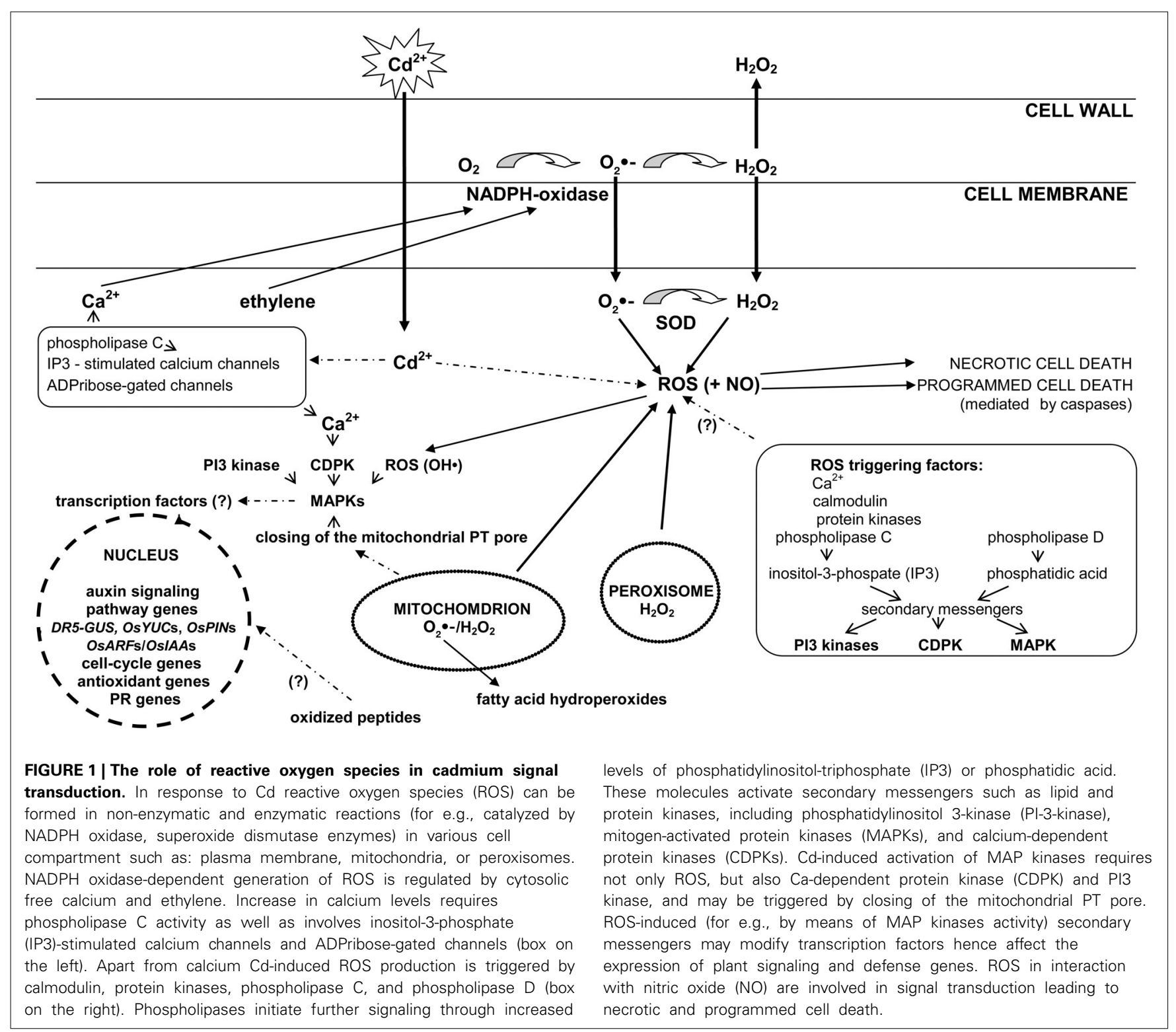

and concentration of metal used, the duration of stress treatment, the plant species and developmental phase of the model plant, as well as the plant tissue or organ analyzed (Xiong et al., 2010). Enhanced NO synthesis has been observed in plant roots even within the first several hours of Cd exposure (Besson-Bard et al., 2009; Mahmood et al., 2009; Arasimowicz-Jelonek et al., 2012). In turn, prolonged treatment to the metal visibly diminishes $\mathrm{NO}$ content in roots (Rodríguez-Serrano et al., 2006; Xu et al., 2010). Endogenous NO was found to also be involved in distal signaling during Cd stress, since Cd application at the root level triggered NO formation in leaves, mainly in the vascular bundles and surrounding cells (Besson-Bard et al., 2009; Arasimowicz-Jelonek et al., 2012).

Many experimental designs using NO donors have revealed that exogenous NO might alleviate cadmium toxicity in plants. The application of $\mathrm{NO}$ in different forms and doses induced a decrease in Cd accumulation (Xiong et al., 2009) or activated the enzymatic antioxidant system, preventing metal-evoked oxidative stress in plant cells (Kopyra and Gwóźdź, 2003; Laspina et al., 2005; Singh et al., 2008). Moreover, exogenous NO was able to improve $\mathrm{Cd}$ tolerance by maintaining auxin equilibrium and enhancing ion absorption (Xu et al., 2010). Most recently, a pharmacological approach performed by Shi et al. (2014) demonstrated interaction between $\mathrm{NO}$ and another gaseous signal molecule, $\mathrm{H}_{2} \mathrm{~S}$, during $\mathrm{Cd}$ stress, which may be essential for plant stress response to the heavy metal. Finally, NO can regulate cellular response via the induction of Cd-dependent signalingassociated genes, including ACS, MAPKK2, DOF1, and MYBZ2 (Chmielowska-Bąk and Deckert, 2013).

An early endogenous NO accumulation in response to Cd was found to be implicated in PCD induction in both a cell suspension (De Michele et al., 2009; Ma et al., 2010) and a whole plant model system (Arasimowicz-Jelonek et al., 2012; Ye et al., 2013). Most probably NO participates in controlling the threshold for 
Table 2 | The effects of various Cd doses on NO generation in plants.

\begin{tabular}{|c|c|c|c|c|}
\hline Species/organ & $\begin{array}{l}\text { Cadmium } \\
\text { concentration }\end{array}$ & Time of treatment & $\begin{array}{l}\text { Changes in NO } \\
\text { level }\end{array}$ & References \\
\hline White poplar (Populus alba L.)/suspension culture & $150 \mu \mathrm{M}$ & $30 \mathrm{~min}$ & $\uparrow$ & Balestrazzi et al., 2009 \\
\hline $\begin{array}{l}\text { Tobacco (Nicotiana tabacum L. cv. Bright Yellow } \\
\text { 2)/BY-2 cells }\end{array}$ & $150 \mu \mathrm{M}$ & $2-12 \mathrm{~h}$ & $\uparrow$ & Ma et al., 2010 \\
\hline Wheat (Triticum aestivum L.)/roots & $10 \mu \mathrm{M}$ & $3 h$ & $\uparrow$ & Mahmood et al., 2009 \\
\hline Soybean (Glycine max L.)/roots & $40 \mu \mathrm{M}$ & $6 \mathrm{~h}$ & $\uparrow$ & Pérez-Chaca et al., 2014 \\
\hline Arabidopsis thaliana/roots & $200 \mu \mathrm{M}$ & $7 \mathrm{~h}$ & $\uparrow$ & Besson-Bard et al., 2009 \\
\hline Yellow lupine (Lupinus luteus L.)/roots & $89 \mu \mathrm{M}$ & 12 and $24 \mathrm{~h}$ & $\uparrow$ & Arasimowicz-Jelonek et al., 2012 \\
\hline Barley (Hordeum vulgare L.)/root tips & $1 \mathrm{mM}$ & $24 \mathrm{~h}$ & $\uparrow$ & Valentovičová et al., 2010 \\
\hline Rice (Oryza sativa L.)/roots & $100 \mu \mathrm{M}$ & $24 \mathrm{~h}$ & $\downarrow$ & Xiong et al., 2009 \\
\hline Pea (Pisum sativum L.)/roots & $100 \mu \mathrm{M}$ & 24 and $48 h$ & $\uparrow$ & Lehotai et al., 2011 \\
\hline Arabidopsis thaliana/suspension culture & $150 \mu \mathrm{M}$ & $48 \mathrm{~h}$ & $\uparrow$ & De Michele et al., 2009 \\
\hline Soybean (Glycine max L.)/suspension culture & $\begin{array}{l}4 \mu \mathrm{M} \\
7 \mu \mathrm{M}\end{array}$ & $72 \mathrm{~h}$ & $\uparrow$ & Kopyra et al., 2006 \\
\hline Wheat (Triticum aestivum L.)/roots & $100 \mu \mathrm{M}$ & 5 days & $\uparrow$ & Groppa et al., 2008a \\
\hline Pea (Pisum sativum L.)/leaves & $50 \mu \mathrm{M}$ & 14 days & $\downarrow$ & Rodríguez-Serrano et al., 2009 \\
\hline Pea (Pisum sativum L.)/roots & $50 \mu \mathrm{M}$ & 14 days & $\downarrow$ & Rodríguez-Serrano et al., 2006 \\
\hline Pea I (Pisum sativum L.)/leaves & $50 \mu \mathrm{M}$ & 14 days & $\downarrow$ & Barroso et al., 2006 \\
\hline Wheat (Triticum aestivum L.)/roots & $1 \mu \mathrm{M}$ & 28 days & $\uparrow$ & Mahmood et al., 2009 \\
\hline
\end{tabular}

triggering PCD in plants. In Arabidopsis cells, both $\mathrm{H}_{2} \mathrm{O}_{2}$ and NO were necessary to trigger PCD, whereas in lupine roots $\mathrm{O}_{2}^{-}$ rather than $\mathrm{H}_{2} \mathrm{O}_{2}$ functions as the molecule that synergizes with NO to unlock the PCD program under Cd stress (De Michele et al., 2009; Arasimowicz-Jelonek et al., 2012). Additionally, Ye et al. (2013) documented that the mechanism of NO function in Cd-induced PCD in Arabidopsis involved MPK6-mediated caspase-3-like protease activation.

Recent published reports have demonstrated that endogenously produced NO plays a key role in the regulation of $\mathrm{Cd}$ cytotoxicity (Groppa et al., 2008a; Besson-Bard et al., 2009; De Michele et al., 2009; Elviri et al., 2010; Valentovičová et al., 2010). NO formation during Cd stress may be strictly related to iron deficiency caused by the metal (Besson-Bard et al., 2009; Besson-Bard and Wendehenne, 2009). In Arabidopsis roots, NO initiated the Fe-starvation pathway, promoting up-regulation of the expression of iron acquisition-related genes (IRT1, FRO2, and FIT) and, in consequence, amplifying Cd accumulation and the subsequent inhibition of root growth (Besson-Bard et al., 2009). In barley root tips, NO was associated in the metal toxicity mechanism through ectopic and accelerated differentiation, causing a shortening of the root elongation zone (Valentovičová et al., 2010). Cd-induced NO formation was also directly correlated with wheat root growth inhibition (Groppa et al., 2008a). What is more, in an Arabidopsis culture, enhanced NO production reduced the efficiency of $\mathrm{Cd}$ ion detoxication through direct S-nitrosylation of phytochelatins, promoting the deleterious effects of Cd (De Michele et al., 2009; Elviri et al., 2010).

\section{PLANT GROWTH REGULATORS}

Plants exposed to abiotic stress often resemble plants with an altered phytohormone metabolism (Pasternak et al., 2005). Numerous papers clearly indicate that plant growth regulators are substantially involved in the perception of and downstream response to cadmium treatment. Changes in the hormonal balance are potential signals initiating plant responses to cadmium stress, including hormone crosstalk with the whole plant signaling network, such as the MAPK (Zhao et al., 2013), ROS (Liptáková et al., 2012; Yuan et al., 2013), and NO signaling pathways (Xu et al., 2011; Wang et al., 2013). Unfortunately, the exact nature of these relations remain somewhat obscure and largely dependent on the experimental background, i.e., the species, the plant organ, the concentration of metal used, and the duration of metal treatment (Table 3). The majority of experimental data indicate that stress growth regulators such as ethylene, SA, JA, and $\mathrm{ABA}$ are involved in the signaling and defense response, but the contribution of other hormones (auxin, cytokinins) cannot be excluded (Al-Hakimi, 2007). In fact, an increase in ethylene (ET) biosynthesis under cadmium treatment was observed in many plant species, including Arabidopsis (Arteca and Arteca, 2007), mustard (Masood et al., 2012), soybean (ChmielowskaBak et al., 2013b), and pea (Rodríguez-Serrano et al., 2009). Experiments with young soybean seedlings revealed that an increase in ET concentration was accompanied not only with the induction of the genes encoding the enzymes of the ethylene biosynthesis pathways, but also the genes related to the proteins involved in the polyamine metabolism, NO generation, and MAPK cascades (Chmielowska-Bąk et al., 2013b). In mustard plants, an increase in ethylene concentration was correlated with augmented 1-aminocyclopropane-1-carboxylic acid synthase activity (ACS), a key enzyme in the ethylene biosynthesis pathway (Masood et al., 2012). Furthermore, experiments performed on bean and onion plants with the use of an inhibitor of ethylene synthesis (Maksymiec, 2011), and tomato mutants with the antisense ACS gene (Liu et al., 2008) pointed to ethylene as a link in Cd-induced accumulation of $\mathrm{H}_{2} \mathrm{O}_{2}$. Ethylene together 
Table 3 | Exemplary studies of growth regulators level (endogenous) under different experimental background.

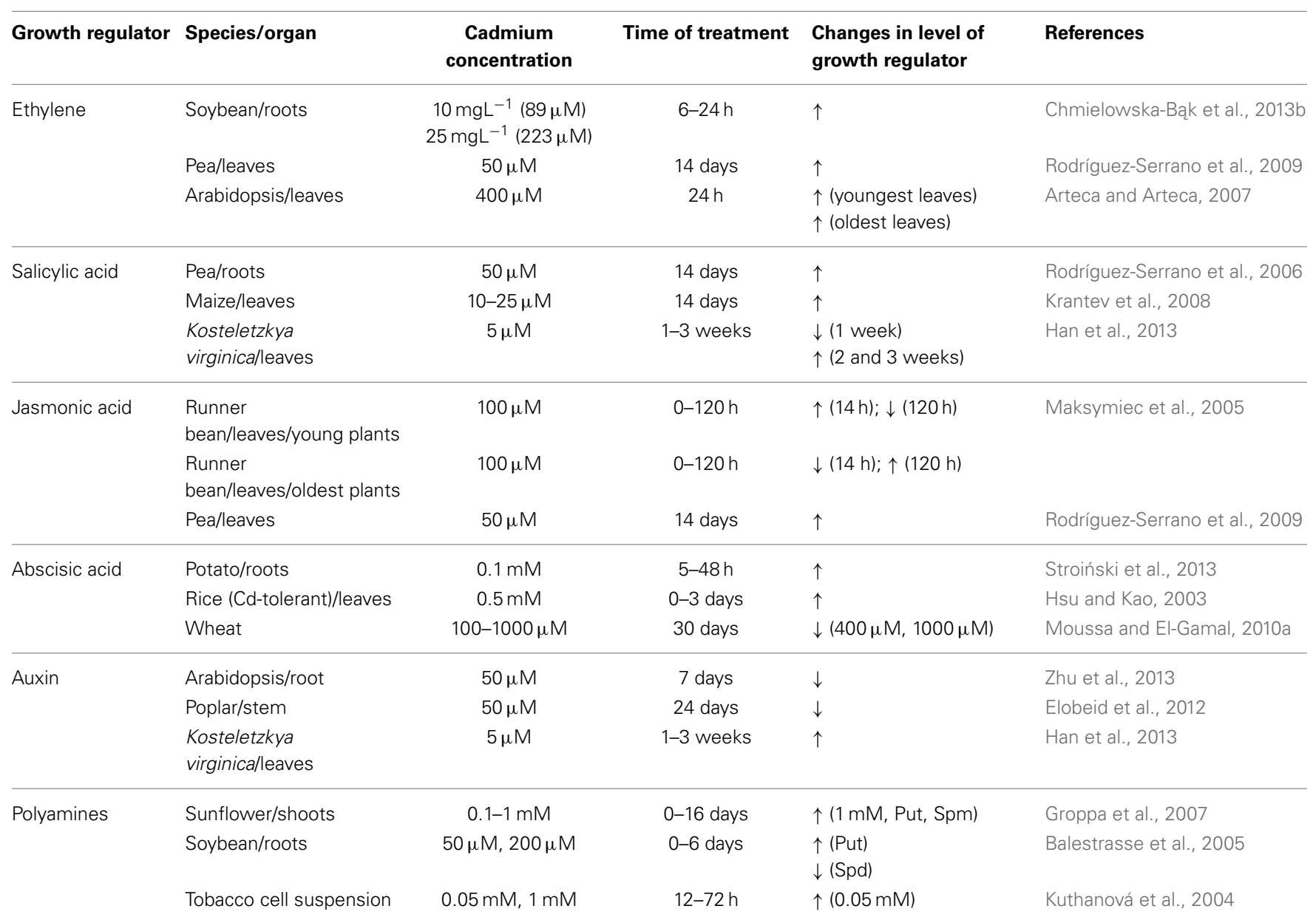

$\uparrow$, Increase in level; $\downarrow$, Decrease in level. Put, putrescine; Spd, spermidine; Spm, spermine. For more details, see References.

with increased $\mathrm{H}_{2} \mathrm{O}_{2}$ production and the activation of the PLC and PLD signaling pathways seems to be involved in the induction of apoptosis in tomato suspension cultures treated with $\mathrm{Cd}$ (Yakimova et al., 2006). On the other hand, experiments on mustard plants treated with ethylene biosynthesis inhibitor strongly suggest that ET plays an important role in the alleviation of $\mathrm{Cd}$ stress on photosynthesis via modulation of the sulfur metabolism and GSH synthesis (Masood et al., 2012). In turn, a comparison of ethylene-insensitive mutant and control tomato plants revealed a very similar pattern of Cd-induced response in terms of growth parameters, metal accumulation, lipid peroxidation, $\mathrm{H}_{2} \mathrm{O}_{2}$ production, and in the activity of most antioxidant enzymes (Monteiro et al., 2011). However, the mutant showed augmented $\mathrm{H}_{2} \mathrm{O}_{2}$ production and enhanced ascorbate peroxidase activity in its fruit, and reduced leaf chlorophyll degradation, indicating that ethylene signaling can modulate the biochemical pathways of oxidative stress in a tissue-dependent manner.

In addition to ethylene, SA and JA also seem to play a role in cadmium signal transduction. The accumulation of endogenous SA under cadmium stress has been noted in pea (RodríguezSerrano et al., 2006), maize (Krantev et al., 2008), Arabidopsis (Zawoznik et al., 2007), and halophyte Kosteletzkya virginica
(Han et al., 2013). The significance of endogenous SA as a signaling molecule necessary to modulate $\mathrm{Cd}$-induced oxidative stress has been well-demonstrated on SA-accumulating and SA-deficient lines of Arabidopsis (Zawoznik et al., 2007; Tao et al., 2013). Mutants exhibited varying levels of $\mathrm{H}_{2} \mathrm{O}_{2}$, lipid peroxidation, and antioxidant enzyme activity compared to wild plants. High endogenous SA significantly increased Cd-induced plant growth retardation, whereas SA deficiency decreased the growth inhibition. However, the majority of reports concern the effect of exogenous application of SA. In most studies, SA displays a protective effect via alleviation of $\mathrm{Cd}$-induced oxidative stress. Modulation of the ROS level (mainly $\mathrm{H}_{2} \mathrm{O}_{2}$ ) and the activity of the antioxidant system after SA pretreatment was observed in many different species, including maize (Krantev et al., 2008), rice (Panda and Patra, 2007), mung bean and common vetch (Zhang et al., 2011), flax (Belkadhi et al., 2013), Kentucky bluegrass (Guo et al., 2013), and mustards plants (Ahmad et al., 2011). It has also been suggested that $\mathrm{SA}$-induced protection against $\mathrm{Cd}$ oxidative stress is mediated through $\mathrm{H}_{2} \mathrm{O}_{2}$ accumulation produced by NADPH oxidase (Chao et al., 2010). Moreover, experiments on ryegrass plants (Wang et al., 2013) and lupine seedlings (Arasimowicz-Jelonek et al., 2012) imply intensive cross-talk 
among $\mathrm{SA}, \mathrm{H}_{2} \mathrm{O}_{2}$ and $\mathrm{NO}$ in long-distance signaling pathways under cadmium treatment. SA also seems to play a protective role in photosynthesis. Plants pretreated with SA and subjected to $\mathrm{Cd}$ challenge showed a diminished reduction in chlorophyll content and/or photosynthetic enzyme activity (Krantev et al., 2008; Popova et al., 2009; Moussa and El-Gamal, 2010a). On the other hand, castor beans pretreated with SA and exposed to Cd displayed potentiated symptoms of Cd toxicity in terms of plant growth and photosynthetic parameters (Liu et al., 2011). All these reports suggest that the mode of SA action depends on the concentration of SA and the plant's susceptibility to this hormone. The lack of a clear tendency following cadmium treatment can also be observed in another stress hormone, namely JA. Elevated levels of JA have been noted in several plant species treated with cadmium, including pea (Rodríguez-Serrano et al., 2006), runner bean, and Arabidopsis plants (Maksymiec et al., 2005). It has been suggested that JA has a protective effect against $\mathrm{Cd}$ action at lower concentrations (Maksymiec and Krupa, 2002; Noriega et al., 2012). However, at higher concentrations $\left(10^{-4} \mathrm{~mol} / \mathrm{L}\right)$, it may induce changes usually observed under heavy metal stress, such as growth reduction, chlorophyll degradation, and inhibition of various photosynthetic parameters (Maksymiec and Krupa, 2002). JA might also interact with ROS signaling-it has been shown to mediate the generation of ROS in Arabidopsis plants exposed to cadmium (Maksymiec and Krupa, 2006).

The response of ABA to cadmium is also ambiguous and depends on the experimental background. An increase in hormone concentrations has been reported in potato plants (Stroiński et al., 2013), halophyte Kosteletzkya virginica (Han et al., 2013), and two rice cultivars, however a Cd-tolerant rice cultivar showed much greater ABA accumulation (Hsu and Kao, 2003). Moreover, exogenous application of ABA resulted in enhanced tolerance to cadmium stress and a decrease in uptake of this heavy metal in a sensitive rice cultivar. Experiments on potato plants treated with $\mathrm{Cd}$ and an inhibitor of ABA biosynthesis implicated the participation of ABA in the transduction of the $\mathrm{Cd}$ signal to the cells of potato roots and phytochelatin synthesis via increased phytochelatin synthase activity (Stroiński et al., 2013). The protective role of ABA against cadmium stress has also been demonstrated by experiments comparing wild type Arabidopsis plants and ABA-deficient plants, in which the mutants proved to be more sensitive to the metal (Sharma and Kumar, 2002). These findings strongly suggest that ABA may be involved in signal pathways during $\mathrm{Cd}$ stress. Moreover, ABA might also initiate the production of metal detoxification compounds (i.e., phytochalatins) and influence the metabolic regulation of other hormones, such as cytokinins (Hayward et al., 2013). Bioinformatic analysis of the promoter sequences of Cd-inducible genes in soybean seedlings revealed that their promoters possess several regulative motifs associated with plant response to stress factors, $\mathrm{ABA}$, and ethylene signaling (Chmielowska-Bak et al., 2013b). On the other hand, studies of ABA-deficient and ABA-insensitive mutants of Arabidopsis excluded a direct mediatory role for ABA in Cdimposed phytotoxic effects on germination and growth assays (Sharma and Kumar, 2002). A decrease in ABA content has also been observed in wheat plants treated with 400 and $1000 \mu \mathrm{M}$ of $\mathrm{CdCl}_{2}$ (Moussa and El-Gamal, 2010b).
Auxin (IAA) is crucial plant growth hormone controlling physiological and developmental processes, but its involvement in cadmium response is still poorly recognized. An increasing body of evidence indicates that cadmium disturbs auxin homeostasis by affecting its level, distribution, metabolism, transport, and balance with other phytohormones (Elobeid et al., 2012; Hu et al., 2013). The modulation of endogenous auxin concentrations after Cd treatment has been observed in Arabidopsis (Zhu et al., 2013), halophyte Kosteletzkya virginica (Han et al., 2013), and poplar (Elobeid et al., 2012), but, similar to other phytohormones, there is no clear tendency. Experiments with auxin inhibitor have demonstrated the involvement of the hormone in the effective alleviation of $\mathrm{Cd}$-induced root growth inhibition, $\mathrm{H}_{2} \mathrm{O}_{2}$ production, and root swelling, but only at a low concentration $(10 \mu \mathrm{M})$ of the metal (Tamas et al., 2012). Additionally, the application of exogenous auxin might alleviate $\mathrm{Cd}$ toxicity in plants by inhibiting heavy metal biosorption, reducing Cd translocation, or stimulating antioxidant enzymes (Piotrowska-Niczyporuk et al., 2012; Zhu et al., 2013). Moreover, auxin signaling might also be involved in defense response to Cd-stress by activation of a detoxification enzyme (Bočová et al., 2013). In general, the concentration and distribution of auxin under cadmium stress seems to be modulated by the regulation of auxin metabolism gene expression through, e.g., the MAPKs cascade and ROS signaling pathways (Zhao et al., 2011, 2013; Hu et al., 2013). Another possibility is increased activity of enzymes involved in the inactivation and/or degradation of the hormone (Chaoui et al., 2004; Elobeid et al., 2012).

Apart from phytohormones, polyamines (PA) such as putrescine (Put), spermidine (Spd), and spermine (Spm) have been proven to play a crucial role in the signaling network and plant defense to cadmium. The pathways of the PA metabolism may crosstalk with other signaling molecules, such as phytohormones, ROS, and NO (Groppa et al., 2008a; Yang et al., 2013). The modulation effect of cadmium on polyamine concentration and the activity of their biosynthesis enzymes was observed in a variety of plant species, including frogbit (Yang et al., 2013), sunflower, wheat (Groppa et al., 2003, 2008b), Potamogeton crispus (Yang et al., 2010), mungbean (Choudhary and Singh, 2000), carnation (Serrano-Martínez and Casas, 2011), soybean (Balestrasse et al., 2005), and tobacco cells (Kuthanová et al., 2004). Most of the data indicate the protective role of polyamines in $\mathrm{Cd}$ stress response. Experiments with exogenous PA application have provided evidence for the important role of polyamines (Spd and Spm) in cadmium stress by influencing the expression and function of the antioxidant system (Groppa et al., 2001; Wen et al., 2011; Kumar et al., 2012; Piotrowska-Niczyporuk et al., 2012), a reduction in ROS generation, and the prevention of lipid peroxidation (Yang et al., 2013). In addition, an experimental approach with antisense inhibition in a Spd synthase gene revealed increased lipid peroxidation and ineffective induction of the antioxidant system in a transgenic pear plant as compared to the wild type (Wen et al., 2011). All of these findings indicate that polyamines are key biological compounds in the signaling network, but like other growth regulators, the specific response under cadmium stress seems to depend on the species, applied concentrations, and time of exposure to the metal. 


\section{MITOGEN-ACTIVATED PROTEIN KINASE CASCADES}

An increasing body of evidence suggests that in plants, MAPKs cascades may function in the Cd-signaling pathways and play an essential role in plant defense or stress responses against metal. Differentiated levels of MAP kinases gene expression have been observed in Cd-exposed seedlings and cell suspensions of rice (Agrawal et al., 2003; Kim et al., 2003; Yeh et al., 2004), Arabidopsis plants (Opdenakker et al., 2012), and soybean seedlings (Chmielowska-Bąk et al., 2013b). In addition, exposure to cadmium ions activated four distinct MAPKs (SIMK, MKK2, MKK3, SAMK) in alfalfa seedlings (Jonak et al., 2004) and two (MPK3, MPK6) in Arabidopsis (Liu et al., 2010). Activation of the plant MAPK cascade by $\mathrm{Cd}$ is achieved within minutes and is probably mediated through distinct signaling pathways, including ROS (Yeh et al., 2007; Liu et al., 2010), $\mathrm{Ca}^{2+}$-dependent protein kinase, and phosphatidylinositol 3-kinase (Yeh et al., 2007). Furthermore, experiments with a mitochondrial permeability transition pore opening blocker indicated that Cd-induced MAP kinase activities are dependent on the functional state of mitochondria (Yeh et al., 2007). Moreover, the NO signaling pathway followed by MAP kinase activation is probably involved in Cd-induced PCD. In Arabidopsis plants, the metal-induced activity of caspase-3-like protease was promoted by increased NO production via up-regulation of MPK6 activity (Ye et al., 2013).

\section{REGULATION OF GENES EXPRESSION}

Exposure to cadmium leads to the changes in expression of numerous genes. The microarray analysis revealed that this metal modulates expression of nearly 400 genes in Arabidopsis and more than 1700 in rice (Kovalchuk et al., 2005; Ogawa et al., 2009). Cadmium has been shown to up-regulate genes encoding pathogen related proteins, antioxidant enzymes, transporters, TFs, and proteins associated with glutathione metabolism. In turn genes encoding proteins connected with photosynthesis were down-regulated in response to short-term cadmium stress (Fusco et al., 2005; Ogawa et al., 2009). The extensive impact of this heavy metal on gene activity requires engagement of various gene regulating mechanisms. Data from the literature imply that Cddependent regulation of genes expression is mediated by changes in the activity of TFs, the modulation of micro RNA levels, and modifications in chromatin.

Plants possess an average of 590 TFs grouped in various families usually named after their DNA-binding motifs (Charoensawan et al., 2010). The response to cadmium stress involves TFs belonging to the MYB, HSF, bZIP, WRKY, and DREB families. Analysis of the expression levels of over 160 genes encoding the TFs belonging to the MYB family in Arabidopsis showed that $20 \%$ of them were affected by cadmium and salt stress (Yanhui et al., 2006). Also, in soybean roots short-term cadmium stress caused induction in the gene encoding MYBZ2 (Chmielowska-Bąk et al., 2013b). In turn, wheat and rice plants treated with cadmium were characterized by an elevated expression of the HsfA4 gene. Moreover, plants over-expressing this TF were more tolerant to cadmium stress, while plants with hampered HsfA4 expression exhibited reduced resistance to this metal (Shim et al., 2009). Among the TFs belonging to the bZIP family, bZIP62, ThbZIP1, and BjCdR15 were shown to be involved in plant response to cadmium stress. The gene encoding bZIP62 was induced by cadmium in soybean roots, while ThbZIP1 showed increased expression in Tamarix hispida (Wang et al., 2010; Chmielowska-Back et al., 2013b). Transgenic Arabidopsis plants over-expressing BjCdR15 exhibited higher tolerance to cadmium accompanied by a higher accumulation of this metal in leaves. It is suggested that $\mathrm{BjCdR} 15$ confers resistance to cadmium through regulation of its root-to-shoot translocation and induced phytochelatin synthesis (Farinati et al., 2010). Analysis of microarray expression profiles demonstrated that exposure to cadmium leads to an elevated expression of OsDREB1A, OsDREB1B, and WKRY09 in rice and TFs belonging to the ATAF, DREB2A, bZIP, and WRKY families in Arabidopsis (Suzuki et al., 2001; Ogawa et al., 2009). Cd-dependent induction of WKRY25 and WRKY29 genes in Arabidopsis has also been proven by the real-time PCR technique (Opdenakker et al., 2012). In opposition to the described results, it has been demonstrated in Solanum torvum plants that exposure to this metal leads to inhibited expression of TFs belonging to the DREB family (Yamaguchi et al., 2010). The described examples show that cadmium affects the mRNA levels of various TFs. This metal might also influence TF activity through changes in their structure. Experiments performed with the use of the NMR technique revealed that $\mathrm{Cd}^{2+}$ replaces $\mathrm{Zn}^{2+}$ in a basic leucine zipper motif in the SUPERMAN (SUP37) TF isolated from Arabidopsis. The described substitution leads to changes in SUP37 conformation which can alter its DNA binding ability (Malgieri et al., 2011). Cadmium stress might also influence TF structure indirectly through the induction of NO production. It has been demonstrated that NO-dependent nitrosylation of cysteine residues in the AtMYB2 transcription factor leads to hampered DNA binding (Serpa et al., 2007).

TFs bind to defined DNA sequences called cis-acting elements. In bean plants, a cis-acting sequence called PvSr2 was shown to be associated with heavy metal stress. Transgenic tobacco plants containing the PvSr2 sequence exhibited an increased expression of the reporter gene in response to $\mathrm{Cu}^{2+}, \mathrm{Zn}^{2+}, \mathrm{Hg}^{2+}$, and $\mathrm{Cd}^{2+}$ (Qi et al., 2007). Analysis of cis-acting elements is useful not only in the search for metal-responsive sequences, but also in uncovering the signaling molecules involved in Cd-dependent gene regulation. In soybean, Cd-responsive genes contained in their promoter region elements associated with ethylene and ABA signaling suggesting that these plant hormones are involved in the response to cadmium stress (Chmielowska-Bąk et al., 2013b). In fact, as it is described in the section concerning plant hormones, the induction of ethylene synthesis by cadmium was noted in various plant species (Rodríguez-Serrano et al., 2006; Arteca and Arteca, 2007; Masood et al., 2012; Chmielowska-Bąk et al., 2013b).

The levels of transcribed mRNA can be regulated by micro RNAs. Recent research shows that cadmium stress affects the levels of miRNAs in rice, soybean, and rape plants (Ding et al., 2011; Zhou et al., 2012; Fang et al., 2013; Zhang et al., 2013). In rice, 19 miRNAs were sensitive to this heavy metal. Interestingly, only one of them, miR528, was induced by cadmium, while the other 18 exhibited diminished expression. The affected miRNAs were involved in the regulation of the genes encoding signaling elements, including the TFs and proteins involved in miRNA 
processing. Inhibited expression of miR168, miR166, and miR390 was correlated with elevated levels of the target mRNAs encoding the AGO protein, HD-Zip TF, and protein kinase, similar to RLK (Ding et al., 2011). Extensive microarray analysis of 953 soybean miRNAs showed that 14 of them were affected by cadmium stress in Cd-tolerant Huaxia3 cultivar and 21 in Cdsensitive cultivar Zhonghuang24. Their target transcripts were involved in various processes, including development, reproduction, metabolism, and response to stimuli (Fang et al., 2013). Cadmium also caused changes in the levels of several miRNAs in the roots and shoots of rape. The affected miRNAs included miR395. More detailed research concerning the involvement of miR395 in plant response to cadmium demonstrated that this molecule is involved in cadmium uptake, root-to-shoot translocation, the alleviation of oxidative stress, and regulation of the expression of the genes encoding phytochelatines and one of the sulfur transporters, Sultr1;1 (Zhou et al., 2012; Zhang et al., 2013).

The expression of genes can be influenced by changes in chromatin, including histone modifications and DNA methylation. Increased levels of methylated DNA is associated with the repression of genes activity and vice versa-hypomethylation loosens the chromatin structure and facilitates genes activation (Chinnusamy and Zhu, 2009). Several studies report that cadmium modulates the levels of DNA methylation in animals and plants; however, there is no clear pattern in the observed changes. In the case of plants, hypermethylation has been observed in radish plants and Posidonia oceanic. In the latter case, increased methylation was correlated with elevated expression of methylotrasferase, indicating the de novo methylation process (Yang et al., 2007; Greco et al., 2012). Hypermethylation was also noted in garden cress in response to lower cadmium concentrations; however, more intense cadmium stress caused a decrease in the levels of DNA methylation (Yanez Barrientos et al., 2013). In turn, in Gracilaria dura exposure to cadmium resulted in a decrease in methylated DNA (Kumar et al., 2012). Significantly, DNA methylation exhibits epigenetic effects. Therefore, at least some of Cd-dependent changes in the pattern of genes expression might be "memorized" and passed on to plant offset.

\section{POST-TRANSCRIPTIONAL MODIFICATION OF PROTEINS}

Protein activity can be influenced not only by changes in the expression levels of encoding mRNAs, but also by post-translation modifications. Heavy metals, including cadmium, can bind to the functional groups of biological molecules, leading to changes in their structure and activity (Latowski et al., 2005; Sharma et al., 2008). Cadmium might also affect protein functions by replacing other divalent ions, such as $\mathrm{Ca}^{2+}$ or $\mathrm{Zn}^{2+}$ (Chmielowska-Bąk et al., 2013a). This type of process, called molecular mimicry, has been observed in radish. Substitution of $\mathrm{Ca}^{2+}$ by $\mathrm{Cd}^{2+}$ in calmodulin resulted in inhibited activity of this sensor protein (Rivetta et al., 1997). Cadmium may also modify proteins indirectly through the induction of ROS and NO accumulation. Over-production of ROS leads to oxidative damage in proteins manifested by protein carbonylation (Braconi et al., 2011). In fact, an increase in the levels of carbonylated proteins has been observed in maize, pea, alfalfa, cucumber, sunflower, and potato plants treated with cadmium (Romero-Puertas et al., 2002; Pena et al., 2006, 2007; Gonçalves et al., 2009). Some of the oxidized proteins in pea plants were identified as Rubisco and antioxidant enzymes namely glutathione reductase, manganese superoxide dismutase and catalase (Romero-Puertas et al., 2002). Interestingly, as it has been described in the section concerning ROS, peptides derived from oxidatively modified proteins might serve as organelle specific signaling molecules (Møller and Sweetlove, 2010).

As has also been mentioned, NO can modify proteins by binding to critical Cys residues, leading to their S-nitrosylation (Arasimowicz-Jelonek and Floryszak-Wieczorek, 2011). The use of the Biotin Switch method has indicated numerous putative protein targets for S-nitrosylation in plants, including various signaling/regulating proteins associated with plant stress responses (Kovacs and Lindermayr, 2013). It has been also shown that under cadmium stress S-nitrosylation affect the activity of catalase and glycolate oxidase (Ortega-Galisteo et al., 2012; Romero-Puertas et al., 2013). S-nitrosylation of the elements involved in signal transduction pathways may lead to alterations in their functioning, as has been observed in the case of the AtMYB2 TF (Serpa et al., 2007).

\section{CONCLUSIONS}

In summary it can be concluded that plants' response to cadmium involves various signaling elements, such as plant hormones, polyamines, calcium ions, ROS, NO, MAPK cascades, TFs, and microRNAs. The mentioned elements are often interrelated with one another and form a complex signaling network. Although significant progress has been made in recent years in the uncovering of the role of compounds participating in this network, there are still many ambiguities:

> It is postulated that peptides derived from oxidatively damaged proteins may act as secondary ROS messengers and regulate specific genes; however, it has not been proven that such an ROS signaling pathway is involved in the response to cadmium stress.

$>$ The role of endogenous NO and other RNS during Cd stress is still very puzzling; therefore, the recognition of the molecular targets of RNS will be an exciting challenge for future research.

$>$ Plant growth regulators are substantially involved in the signaling pathways of plant response to cadmium, but their mutual interaction and exact crosstalk with the overall signaling network is still not fully recognized.

$>$ Recent research implies that cadmium stress leads to the induction of various TFs; however, information concerning their role in plant response to this heavy metal is still scarce.

$>$ There is a lack of research examining whether Cd-dependent changes in the levels of DNA methylation are associated with acquiring long-term resistance to this stress factor that can be memorized and passed to the offset.

\section{ACKNOWLEDGMENTS}

Research concerning cadmium sensing in plants is conducted in the Laboratory of Plant Ecophysiology with the financial support of National Science Center in Poland (decision no. 
DEC-2011/03/N/NZ9/00214) and Ministry of Science and Higher Education (grant no. N N303 537938)

\section{REFERENCES}

Agrawal, G. K., Rakwal, R., and Iwahashi, H. (2002). Isolation of novel rice (Oryza sativa L.) multiple stress responsive MAP kinase gene, OsMSRMK2, whose mRNA accumulates rapidly in response to environmental cues. Biochem. Biophys. Res. Commun. 294, 1009-1016. doi: 10.1016/S0006-291X(02) 00571-5

Agrawal, G. K., Tamogami, S., Iwahashi, H., Agrawal, V. P., and Rakwal, R. (2003). Transient regulation of jasmonic acid-inducible rice MAP kinase gene (OsBWMK1) by diverse biotic and abiotic stresses. Plant Physiol. Biochem. 41, 355-361. doi: 10.1016/S0981-9428(03)00030-5

Ahmad, P., Nabi, G., and Ashraf, M. (2011). Cadmium-induced oxidative damage in mustard [Brassica juncea (L.) Czern. \& Coss.] plants can be alleviated by salicylic acid. S. Afr. J. Bot. 77, 36-44. doi: 10.1016/j.sajb.2010.05.003

Al-Hakimi, A. M. A. (2007). Modification of cadmium toxicity in pea seedlings by kinetin. Plant Soil Environ. 53, 129-135.

Arasimowicz-Jelonek, M., and Floryszak-Wieczorek, J. (2011). Understanding the fate of peroxynitrite in plant cells - from physiology to pathophysiology. Phytochemistry 72, 681-688. doi: 10.1016/j.phytochem.2011.02.025

Arasimowicz-Jelonek, M., Floryszak-Wieczorek, J., Deckert, J., RucińskaSobkowiak, R., Gzyl, J., Pawlak-Sprada, S., et al. (2012). Nitric oxide implication in cadmium-induced programmed cell death in roots and signaling response of yellow lupine plants. Plant Physiol. Biochem. 58, 124-134. doi: 10.1016/j.plaphy.2012.06.018

Arteca, R. N., and Arteca, J. M. (2007). Heavy-metal induced ethylene production in Arabidopsis thaliana. J. Plant Physiol. 164, 1480-1488. doi: 10.1016/j.jplph.2006.09.006

Balestrasse, K. B., Gallego, S. M., Benavides, M. P., and Tomaro, M. L. (2005). Polyamines and proline are affected by cadmium stress in nodules and roots of soybean plants. Plant Soil 270, 343-353. doi: 10.1007/s11104-004-1792-0

Balestrazzi, A., Macovei, A., Testoni, C., Raimondi, E., Donà, M., and Carbonera, D. (2009). Nitric oxide biosynthesis in white poplar (Populus alba L.) suspension cultures challenged with heavy metals. Plant Stress 3, 1-6.

Barroso, J. B., Corpas, F. J., Carreras, A., Rodriguez-Serrano, M., Estaban, F. J., Fernández-Ocaña, A., et al. (2006). Localization of S-nitrosoglutathione and expression of S-nitrosoglutathione reductase in pea plants under cadmium stress. J. Exp. Bot. 57, 1785-1793. doi: 10.1093/jxb/erj175

Belkadhi, A., De Haro, A., Soengas, P., Obregon, S., Cartea, M. E., Djebali, W., et al. (2013). Salicylic acid improves root antioxidant defense system and total antioxidant capacities of flax subjected to cadmium. OMICS 17, 398-406. doi: 10.1089/omi.2013.0030

Besson-Bard, A., Gravot, A., Richaud, P., Auroy, P., Duc, C., Gaymard, F., et al. (2009). Nitric oxide contributes to cadmium toxicity in Arabidopsis by promoting cadmium accumulation in roots and by up-regulating genes related to iron uptake. Plant Physiol. 149, 1302-1315. doi: 10.1104/pp.108.133348

Besson-Bard, A., and Wendehenne, D. (2009). NO contributes to cadmium toxicity in Arabidopsis thaliana by mediating an iron deprivation response. Plant Signal. Behav. 4, 252-254. doi: 10.4161/psb.4.3.8032

Bočová, B., Huttová, J., Mistrík, I., and Tamás, L. (2013). Auxin signalling is involved in cadmium-induced glutathione-S-transferase activity in barley root. Acta Physiol. Plant. 35, 2685-2690. doi: 10.1007/s11738-013-1300-3

Braconi, D., Bernardini, G., and Santucci, A. (2011). Linking protein oxidation to environmental pollutants: redox proteomic approaches. J. Proteomics 74, 2324-2337. doi: 10.1016/j.jprot.2011.06.029

Chao, Y. Y., Chen, C. Y., Huang, W. D., and Kao, C. H. (2010). Salicylic acidmediated hydrogen peroxide accumulation and protection against Cd toxicity in rice leaves. Plant Soil 329, 327-337. doi: 10.1007/s11104-009-0161-4

Chaoui, A., Jarrar, B., and El Ferjani, E. (2004). Effects of cadmium and copper on peroxidase, NADH oxidase and IAA oxidase activities in cell wall, soluble and microsomal membrane fractions of pea roots. J. Plant Physiol. 161, 1225-1234. doi: 10.1016/j.jplph.2004.02.002

Charoensawan, V., Wilson, D., and Teichmann, S. A. (2010). Genomic repertoires of DNA-binding transcription factors across the tree of life. Nucleic Acids Res. 38, 7364-7377. doi: 10.1093/nar/gkq617

Chinnusamy, V., and Zhu, J. K. (2009). Epigenetic regulation of stress responses in plants. Curr. Opin. Plant Biol. 12, 133-139. doi: 10.1016/j.pbi.2008.12.006
Chmielowska-Bąk, J., and Deckert, J. (2013). Nitric oxide mediates Cd-dependent induction of signaling-associated genes. Plant Signal. Behav. 8, e26664. doi: $10.4161 /$ psb.26664

Chmielowska-Bąk, J., Izbiańska, K., and Deckert, J. (2013a). The toxic Doppelganger: on the ionic and molecular mimicry of cadmium. Acta Biochim. Pol. 60, 369-374.

Chmielowska-Bąk, J., Lefèvre, I., Lutts, S., and Deckert, J. (2013b). Short term signaling responses in roots of young soybean seedlings exposed to cadmium stress. J. Plant Physiol. 170, 1585-1594. doi: 10.1016/j.jplph.2013.06.019

Choudhary, A., and Singh, R. P. (2000). Cadmium-induced changes in diamine oxidase activity and polyamine levels in Vigna radiata Wilczek seedlings. J. Plant Physiol. 156, 704-710. doi: 10.1016/S0176-1617(00)80235-7

Colcombet, J., and Hirt, H. (2008). Arabidopsis MAPKs: a complex signalling network involved in multiple biological processes. Biochem. J. 413, 217-226. doi: 10.1042/BJ20080625

De Michele, R., Vurro, E., Rigo, C., Costa, A., Elviri, L., Di Valentin, M., et al. (2009). Nitric oxide is involved in cadmium-induced programmed cell death in Arabidopsis suspension cultures. Plant Physiol. 150, 217-228. doi: 10.1104/pp.108.133397

Ding, Y., Chen, Z., and Zhu, C. (2011). Microarray-based analysis of cadmiumresponsive microRNAs in rice (Oryza sativa). J. Exp. Bot. 62, 3563-3573. doi: 10.1093/jxb/err046

Elobeid, M., Göbel, C., Feussner, I., and Polle, A. (2012). Cadmium interferes with auxin physiology and lignification in poplar. J. Exp. Bot. 63, 1413-1421. doi: 10.1093/jxb/err384

Elviri, L., Speroni, F., Careri, M., Mangia, A., di Toppi, L. S., and Zottini, M. (2010). Identification of in vivo nitrosylated phytochelatins in Arabidopsis thaliana cells by liquid chromatography-direct electrospray-linear ion trap-mass spectrometry. J. Chromatogr. A 1217, 4120-4126. doi: 10.1016/j.chroma.2010.02.013

Fang, X., Zhao, Y., Ma, Q., Huang, Y., Wang, P., Zhang, J., et al. (2013). Identification and comparative analysis of cadmium tolerance-associated miRNAs and their targets in two soybean genotypes. PLoS ONE 8:e81471. doi: 10.1371/journal.pone.0081471

Farinati, S., DalCorso, G., Varotto, S., and Furini, A. (2010). The Brassica juncea BjCdR15, an ortholog of Arabidopsis TGA3, is a regulator of cadmium uptake, transport and accumulation in shoots and confers cadmium tolerance in transgenic plants. New Phytol. 185, 964-978. doi: 10.1111/j.1469-8137.2009.03132.x

Fusco, N., Micheletto, L., Dal Corso, G., Borgato, L., and Furini, A. (2005). Identification of cadmium-regulated genes by cDNA-AFLP in the heavy metal accumulator Brassica juncea L. J. Exp. Bot. 56, 3017-3027. doi: 10.1093/jxb/eri299

Gallego, S. M., Pena, L. B., Barcia, R. A., Azpilicueta, C. E., Iannone, M. F., Rosales, E. P., et al. (2012). Unravelling cadmium toxicity and tolerance in plants: insight into regulatory mechanisms. Environ. Exp. Bot. 83, 33-46. doi: 10.1016/j.envexpbot.2012.04.006

Garnier, L., Simon-Plas, F., Thuleau, P., Agnel, J. P., Blein, J. P., Ranjeva, R., et al. (2006). Cadmium affects tobacco cells by a series of three waves of reactive oxygen species that contribute to cytotoxicity. Plant Cell Environ. 29, 1956-1969. doi: 10.1111/j.1365-3040.2006.01571.x

Gonçalves, J. F., Antes, F. G., Maldaner, J., Pereira, L. B., Tabaldi, L. A., Rauber, R., et al. (2009). Cadmium and mineral nutrient accumulation in potato plantlets grown under cadmium stress in two different experimental culture conditions. Plant Physiol. Biochem. 47, 814-821. doi: 10.1016/j.plaphy.2009.04.002

Greco, M., Chiappetta, A., Bruno, L., and Bitonti, M. B. (2012). In Posidonia oceanica cadmium induces changes in DNA methylation and chromatin patterning. J. Exp. Bot. 63, 695-709. doi: 10.1093/jxb/err313

Groppa, M. D., Benavides, M. P., and Tomaro, M. L. (2003). Polyamine metabolism in sunflower and wheat leaf discs under cadmium or copper stress. Plant Sci. 164, 293-299. doi: 10.1016/S0168-9452(02)00412-0

Groppa, M. D., Ianuzzo, M. P., Tomaro, M. L., and Benavides, M. P. (2007) Polyamine metabolism in sunflower plants under long-term cadmium or copper stress. Amino Acids 32, 265-275. doi: 10.1007/s00726-006-0343-9

Groppa, M. D., Rosales, E. P., Iannone, M. F., and Benavides, M. P. (2008a). Nitric oxide, polyamines and $\mathrm{Cd}$-induced phytotoxicity in wheat roots. Phytochemistry 69, 2609-2615. doi: 10.1016/j.phytochem.2008.07.016

Groppa, M. D., Tomaro, M. L., and Benavides, M. P. (2001). Polyamines as protectors against cadmium or copper-induced oxidative damage in sunflower leaf discs. Plant Sci. 161, 481-488. doi: 10.1016/S0168-9452(01) 00432-0 
Groppa, M. D., Zawoznik, M. S., Tomaro, M. L., and Benavides, M. P. (2008b). Inhibition of root growth and polyamine metabolism in sunflower (Helianthus annuus) seedlings under cadmium and copper stress. Biol. Trace Elem. Res. 126, 246-256. doi: 10.1007/s12011-008-8191-y

Guo, Q., Meng, L., Mao, P. C., Jia, Y. Q., and Shi, Y. J. (2013). Role of exogenous salicylic acid in alleviating cadmium-induced toxicity in Kentucky bluegrass. Biochem. Syst. Ecol. 50, 269-276. doi: 10.1016/j.bse.2013.05.002

Han, R. M., Lefèvre, I., Albacete, A., Pérez-Alfocea, F., Barba-Espín, G., DíazVivancos, P., et al. (2013). Antioxidant enzyme activities and hormonal status in response to $\mathrm{Cd}$ stress in the wetland halophyte Kosteletzkya virginica under saline conditions. Physiol. Plant. 147, 352-368. doi: 10.1111/j.13993054.2012.01667.x

Hayward, A. R., Coates, K. E., Galer, A. L., Hutchinson, T. C., and Emery, R. J. N. (2013). Chelator profiling in Deschampsia cespitosa (L.) Beauv. Reveals a Ni reaction, which is distinct from the $\mathrm{ABA}$ and cytokinin associated response to Cd. Plant Physiol. Biochem. 64, 84-91. doi: 10.1016/j.plaphy.2012.12.018

Heyno, E., Klose, C., and Krieger-Liszkay, A. (2008). Origin of cadmiuminduced reactive oxygen species production: mitochondrial electron transfer versus plasma membrane NADPH oxidase. New Phytol. 179, 687-699. doi: 10.1111/j.1469-8137.2008.02512.x

Hsu, Y. T., and Kao, C. H. (2003). Role of abscisic acid in cadmium tolerance of rice (Oryza sativa L.) seedlings. Plant Cell Environ. 26, 867-874. doi: 10.1046/j.13653040.2003.01018.x

Hsu, Y. T., and Kao, C. H. (2007). Toxicity in leaves of rice exposed to cadmium is due to hydrogen peroxide accumulation. Plant Soil 298, 231-241. doi: 10.1007/s11104-007-9357-7

Hu, Y. F., Zhou, G., Na, X. F., Yang, L., Nan, W. B., Liu, X., et al. (2013). Cadmium interferes with maintenance of auxin homeostasis in Arabidopsis seedlings. J. Plant Physiol. 170, 965-975. doi: 10.1016/j.jplph.2013.02.008

Jonak, C., Nakagami, H., and Hirt, H. (2004). Heavy metal stress. Activation of distinct mitogen-activated protein kinase pathways by copper and cadmium. Plant Physiol. 136, 3276-3283. doi: 10.1104/pp.104.045724

Kim, J. A., Agrawal, G. K., Rakwal, R., Han, K. S., Kim, K. N., Yun, C. H., et al. (2003). Molecular cloning and mRNA expression analysis of a novel rice (Oryza sativa L.) MAPK kinase kinase, OsEDR1, an ortholog of Arabidopsis AtEDR1, reveal its role in defense/stress signalling pathways and development. Biochem. Biophys. Res. Commun. 300, 868-876. doi: 10.1016/S0006-291X(02)02944-3

Kopyra, M., and Gwóźdź, E. A. (2003). Nitric oxide stimulates seed germination and counteracts the inhibitory effect of heavy metals and salinity on root growth of Lupinus luteus. Plant Physiol. Biochem. 41, 1011-1017. doi: 10.1016/j.plaphy.2003.09.003

Kopyra, M., Stachoń-Wilk, M., and Gwóźdź, A. E. (2006). Effects of exogenous nitric oxide on the antioxidant capacity of cadmium-treated soybean cell suspension. Acta Physiol. Plant. 28, 525-536. doi: 10.1007/s11738-006-0048-4

Kovacs, I., and Lindermayr, C. (2013). Nitric oxide-based protein modification: formation and site-specificity of protein S-nitrosylation. Front. Plant Sci. 4:137. doi: 10.3389/fpls.2013.00137

Kovalchuk, I., Titov, V., Hohn, B., and Kovalchuk, O. (2005). Transcriptome profiling reveals similarities and differences in plant responses to cadmium and lead. Mutation Res. 570, 149-161. doi: 10.1016/j.mrfmmm.2004.10.004

Krantev, A., Yordanova, R., Janda, T., Szalai, G., and Popova, L. (2008). Treatment with salicylic acid decreases the effect of cadmium on photosynthesis in maize plants. J. Plant Physiol. 165, 920-931. doi: 10.1016/j.jplph.2006.11.014

Kumar, M., Bijo, A. J., Baghel, R. S., Reddy, C. R. K., and Jha, B. (2012). Selenium and spermine alleviate cadmium induced toxicity in the red seaweed Gracilaria dura by regulating antioxidants and DNA methylation. Plant Physiol. Biochem. 51, 129-138. doi: 10.1016/j.plaphy.2011.10.016

Kuthanová, A., Gemperlová, L., Zelenková, S., Eder, J., Macháčková, I., Opatrný, Z., et al. (2004). Cytological changes and alterations in polyamine contents induced by cadmium in tobacco BY-2 cells. Plant Physiol. Biochem. 42, 149-156. doi: 10.1016/j.plaphy.2003.11.003

Laspina, N. V., Groppa, M. D., Tomaro, M. L., and Benavides, M. P. (2005). Nitric oxide protects sunflower leaves against Cd-induced oxidative stress. Plant Sci. 169, 323-330. doi: 10.1016/j.plantsci.2005.02.007

Latowski, D., Kruk, J., and Strzałka, K. (2005). Inhibition of zeaxanthin epoxidase activity by cadmium ions in higher plants. J. Inorg. Biochem. 99, 2081-2087. doi: 10.1016/j.jinorgbio.2005.07.012

Lehotai, N., Peto, A., Bajkán, S., Erdei, L., Tari, I., and Kolbert, Z. (2011). In vivo and in situ visualization of early physiological events induced by heavy metals in pea root meristem. Acta Physiol. Plant. 33, 2199-2207. doi: 10.1007/s11738011-0759-z

Liptáková, L., Bočová, B., Huttová, J., Mistrík, I., and Tamás, L. (2012). Superoxide production induced by short-term exposure of barley roots to cadmium, auxin, alloxan and sodium dodecyl sulfate. Plant Cell Rep. 31, 2189-2197. doi: 10.1007/s00299-012-1329-6

Liu, C., Guo, J., Cui, Y., Lü, T., Zhang, X., and Shi, G. (2011). Effects of cadmium and salicylic acid on growth, spectral reflectance and photosynthesis of castor bean seedlings. Plant Soil 344, 131-141. doi: 10.1007/s11104-0110733-y

Liu, K., Shen, L., and Sheng, J. (2008). Improvement in cadmium tolerance of tomato seedlings with an antisense DNA for 1aminocyclopropane-1-carboxylate synthase. J. Plant. Nutr. 31, 809-827. doi: 10.1080/01904160802043080

Liu, X. M., Kim, K. E., Kim, K. C., Nguyen, X. C., Han, H. J., Jung, M. S., et al. (2010). Cadmium activates Arabidopsis MPK3 and MPK6 via accumulation of reactive oxygen species. Phytochemistry 71, 614-618. doi: 10.1016/j.phytochem.2010.01.005

Ma, W., Xu, W., Xu, H., Chen, Y., He, Z., and Ma, M. (2010). Nitric oxide modulates cadmium influx during cadmium-induced programmed cell death in tobacco BY-2 cells. Planta 232, 325-335. doi: 10.1007/s00425-010-1177-y

Mahmood, T., Gupta, K. J., and Kaiser, W. M. (2009). Cadmium stress stimulates nitric oxide production by wheat roots. Pak. J. Bot. 41, 1285-1290.

Maksymiec, W. (2011). Effects of jasmonate and some other signalling factors on bean and onion growth during the initial phase of cadmium action. Biol. Plant. 55, 112-118. doi: 10.1007/s10535-011-0015-9

Maksymiec, W., and Krupa, Z. (2002). Jasmonic acid and heavy metals in Arabidopsis plants - a similar physiological response to both stressors? J. Plant Physiol. 159, 509-515. doi: 10.1078/0176-1617-00610

Maksymiec, W., and Krupa, Z. (2006). The effects of short-term exposition to $\mathrm{Cd}$, excess $\mathrm{Cu}$ ions and jasmonate on oxidative stress appearing in Arabidopsis thaliana. Environ. Exp. Bot. 57, 187-194. doi: 10.1016/j.envexpbot.2005.05.006

Maksymiec, W., Wianowska, D., Dawidowicz, A. L., Radkiewicz, S., Mardarowicz, M., and Krupa, Z. (2005). The level of jasmonic acid in Arabidopsis thaliana and Phaseolus coccineus plants under heavy metal stress. J. Plant Physiol. 162, 1338-1346. doi: 10.1016/j.jplph.2005.01.013

Malgieri, G., Zaccaro, L., Leone, M., Bucci, E., Esposito, S., Baglivo, I., et al. (2011). Zinc to cadmium replacement in the A. thaliana SUPERMAN Cys $\mathrm{His}_{2}$ zinc finger induces structural rearrangements of typical DNA base determinant positions. Biopolymers 95, 801-810. doi: 10.1002/bip.21680

Masood, A., Iqbal, N., and Khan, N. A. (2012). Role of ethylene in alleviation of cadmium-induced photosynthetic capacity inhibition by sulphur in mustard. Plant Cell Environ. 35, 524-533. doi: 10.1111/j.1365-3040.2011.02432.x

Møller, I. M., and Sweetlove, L. J. (2010). ROS signalling - specificity is required. Trends Plant Sci. 15, 370-374. doi: 10.1016/j.tplants.2010.04.008

Monteiro, C. C., Carvalho, R. F., Gratão, P. L., Carvalho, G., Tezotto, T., Medici, L. O., et al. (2011). Biochemical responses of the ethylene-insensitive Never ripe tomato mutant subjected to cadmium and sodium stresses. Environ. Exp. Bot. 71, 306-320. doi: 10.1016/j.envexpbot.2010.12.020

Moussa, H. R., and El-Gamal, S. M. (2010a). Effect of salicylic acid pretreatment on cadmium toxicity in wheat. Biol. Plant. 54, 315-320. doi: 10.1007/s10535-0100054-7

Moussa, H. R., and El-Gamal, S. M. (2010b). Role of salicylic acid in regulation of cadmium toxicity in wheat (Triticum aestivum L.). J. Plant. Nutr. 33, 1460-1471. doi: 10.1080/01904167.2010.489984

Noriega, G., Cruz, D. S., Batlle, A., Tomaro, M., and Balestrasse, K. (2012). Heme oxygenase is involved in the protection exerted by jasmonic acid against cadmium stress in soybean roots. J. Plant Growth Regul. 31, 79-89. doi: 10.1007/s00344-011-9221-0

Ogawa, I., Nakanishi, H., Mori, S., and Nishizawa, N. K. (2009). Time course analysis of gene regulation under cadmium stress in rice. Plant Soil 325, 97-108. doi: 10.1007/s11104-009-0116-9

Olmos, E., Martínez-Solano, J. R., Piqueras, A., and Hellín, E. (2003). Early steps in the oxidative burst induced by cadmium in cultured tobacco cells (BY-2 line). J. Exp. Bot. 54, 291-301. doi: 10.1093/jxb/54.381.291

Opdenakker, K., Remans, T., Keunen, E., Vangronsveld, J., and Cuypers, A. (2012). Exposure of Arabidopsis thaliana to $\mathrm{Cd}$ or $\mathrm{Cu}$ excess leads to oxidative stress mediated alterations in MAPKinase transcript levels. Environ. Exp. Bot. 83, 53-61. doi: 10.1016/j.envexpbot.2012.04.003 
Ortega-Galisteo, A. P., Rodríguez-Serrano, M., Pazmiño, D. M., Gupta, D. K., Sandalio, L. M., and Romero-Puertas, M. C. (2012). S-nitrosylated proteins in pea (Pisum sativum L.) leaf peroxisomes: changes under abiotic stress. J Exp Bot 63, 2089-2103. doi: 10.1093/jxb/err414

Ortega-Villasante, C., Hernández, L. E., Rellán-Alvarez, R., Del Campo, F. F., and Carpena-Ruiz, R. O. (2007). Rapid alteration of cellular redox homeostasis upon exposure to cadmium and mercury in alfalfa seedlings. New Phytol. 176, 96-107. doi: 10.1111/j.1469-8137.2007.02162.x

Panda, S. K., and Patra, H. K. (2007). Effect of salicylic acid potentiates cadmiuminduced oxidative damage in Oryza sativa L. leaves. Acta Physiol. Plant. 29, 567-575. doi: 10.1007/s11738-007-0069-7

Pasternak, T., Rudas, V., Potters, G., and Jansen, M. A. K. (2005). Morphogenic effects of abiotic stress: reorientation of growth in Arabidopsis thaliana seedlings. Environ. Exp. Bot. 53, 299-314. doi: 10.1016/j.envexpbot.2004. 04.009

Pena, L. B., Pasquini, L. A., Tomaro, M. L., and Gallego, S. M. (2006). Proteolytic system in sunflower (Helianthus annuus L.) leaves under cadmium stress. Plant Sci. 171, 531-537. doi: 10.1016/j.plantsci.2006.06.003

Pena, L. B., Pasquini, L. A., Tomaro, M. L., and Gallego, S. M. (2007). 20 S proteasome and accumulation of oxidized and ubiquitinated proteins in maize leaves subjected to cadmium stress. Phytochemistry 68, 1139-1146. doi: 10.1016/j.phytochem.2007.02.022

Pérez-Chaca, M. V., Rodríguez-Serrano, M., Molina, A. S., Pedranzani, H. E., Zirulnik, F., Sandalio, L. M., et al. (2014). Cadmium induces two waves of reactive oxygen species in Glycine max (L.) roots. Plant Cell Environ. doi: 10.1111/pce.12280. [Epub ahead of print].

Piotrowska-Niczyporuk, A., Bajguz, A., Zambrzycka, E., and GodlewskaŻyłkiewicz, B. (2012). Phytohormones as regulators of heavy metal biosorption and toxicity in green alga Chlorella vulgaris (Chlorophyceae). Plant Physiol. Biochem. 52, 52-65. doi: 10.1016/j.plaphy.2011.11.009

Popova, L. P., Maslenkova, L. T., Yordanova, R. Y., Ivanova, A. P., Krantev, A. P., Szalai, G., et al. (2009). Exogenous treatment with salicylic acid attenuates cadmium toxicity in pea seedlings. Plant Physiol. Biochem. 47, 224-231. doi: 10.1016/j.plaphy.2008.11.007

Qi, X., Zhang, Y., and Chai, T. (2007). Characterization of a novel plant promoter specifically induced by heavy metal and identification of the promoter regions conferring heavy metal responsiveness. Plant Physiol. 143, 50-59. doi: 10.1104/pp.106.080283

Rivetta, A., Negrini, N., and Cocucci, M. (1997). Involvement of $\mathrm{Ca}^{2+}$-calmodulin in $\mathrm{Cd}^{2+}$ toxicity during the early phases of radish (Raphanus sativus L.) seed germination. Plant Cell Environ. 20, 600-608. doi: 10.1111/j.13653040.1997.00072.x

Rodríguez-Serrano, M., Romero-Puertas, M. C., Pazmino, D. M., Testillano, P. S., Risueno, M. C., Del Río, L. A., et al. (2009). Cellular response of pea plants to cadmium toxicity: cross talk between reactive oxygen species, nitric oxide, and calcium. Plant Physiol. 150, 229-243. doi: 10.1104/pp.108. 131524

Rodríguez-Serrano, M., Romero-Puertas, M. C., Zabalza, A., Corpas, F. J., Gómez, M., Del Río, L. A., et al. (2006). Cadmium effect on oxidative metabolism of pea (Pisum sativum L.) roots. Imaging of reactive oxygen species and nitric oxide accumulation in vivo. Plant Cell Environ. 29, 1532-1544. doi: 10.1111/j.13653040.2006.01531.x

Romero-Puertas, M. C., McCarthy, I., Sandalio, L. M., Palma, J. M., Corpas, F. J., Gómez, M., et al. (1999). Cadmium toxicity and oxidative metabolism of pea leaf peroxisomes. Free Radic. Res. 31, S25-S31. doi: 10.1080/10715769900301281

Romero-Puertas, M. C., Palma, J. M., Gómez, M., Del Río, L. A., and Sandalio, L. M. (2002). Cadmium causes the oxidative modification of proteins in pea plants. Plant Cell Environ. 25, 677-686. doi: 10.1046/j.1365-3040.2002.00850.x

Romero-Puertas, M. C., Rodríguez-Serrano, M., Corpas, F. J., Gómez, M., Del Río, L. A., and Sandalio, L. M. (2004). Cadmium-induced subcellular accumulation of $\mathrm{O}_{2--}$ and $\mathrm{H}_{2} \mathrm{O}_{2}$ in pea leaves. Plant Cell Environ. 27, 1122-1134. doi: 10.1111/j.1365-3040.2004.01217.x

Romero-Puertas, M. C., Rodríguez-Serrano, M., and Sandalio, L. M. (2013). Protein S-nitrosylation in plants under abiotic stress: an overview. Front. Plant Sci. 4:373. doi: 10.3389/fpls.2013.00373

Serpa, V., Vernal, J., Lamattina, L., Grotewold, E., Cassia, R., and Terenzi, H. (2007). Inhibition of AtMYB2 DNA-binding by nitric oxide involves cysteine S-nitrosylation. Biochem. Biophys. Res. Commun. 361, 1048-1053. doi: 10.1016/j.bbrc.2007.07.133

Serrano-Martínez, F., and Casas, J. L. (2011). Effects of extended exposure to cadmium and subsequent recovery period on growth, antioxidant status and polyamine pattern in in vitro cultured carnation. Physiol. Mol. Biol. Plants 17, 327-338. doi: 10.1007/s12298-011-0081-7

Sharma, S. K., Goloubinoff, P., and Christen, P. (2008). Heavy metal ions are potent inhibitors of protein folding. Biochem. Biophys. Res. Commun. 372, 341-345. doi: 10.1016/j.bbrc.2008.05.052

Sharma, S. S., and Kumar, V. (2002). Responses of wild type and abscisic acid mutants of Arabidopsis thaliana to cadmium. J. Plant Physiol. 159, 1323-1327. doi: 10.1078/0176-1617-00601

Shi, H., Ye, T., and Chan, Z. (2014). Nitric oxide-activated hydrogen sulfide is essential for cadmium stress response in bermudagrass (Cynodon dactylon (L). Pers.). Plant Physiol. Biochem. 74, 99-107. doi: 10.1016/j.plaphy.2013.11.001

Shim, D., Hwang, J. U., Lee, J., Lee, S., Choi, Y., An, G., et al. (2009). Orthologs of the class A4 heat shock transcription factor HsfA4a confer cadmium tolerance in wheat and rice. Plant Cell 21, 4031-4043. doi: 10.1105/tpc.109. 066902

Singh, H. P., Batish, D. R., Kaur, G., Arora, K., and Kohli, R. K. (2008). Nitric oxide (as sodium nitroprusside) supplementation ameliorates Cd toxicity in hydroponically grown wheat roots. Environ. Exp. Bot. 63, 158-167. doi: 10.1016/j.envexpbot.2007.12.005

Stroiński, A., Gizewska, K., and Zielezińska, M. (2013). Abscisic acid is required in transduction of cadmium signal to potato roots. Biol. Plant. 57, 121-127. doi: 10.1007/s10535-012-0135-x

Suzuki, N., Koizumi, N., and Sano, H. (2001). Screening of cadmium-responsive genes in Arabidopsis thaliana. Plant Cell Environ. 24, 1177-1188. doi: 10.1046/j.1365-3040.2001.00773.x

Tamas, L., Bočová, B., Huttová, J., Liptáková, L., Mistrík, I., Valentovičová, K., et al. (2012). Impact of the auxin signaling inhibitor p-chlorophenoxyisobutyric acid on short-term Cd-induced hydrogen peroxide production and growth response in barley root tip. J. Plant Physiol. 169, 1375-1381. doi: 10.1016/j.jplph.2012.05.023

Tao, S., Sun, L., Ma, C., Li, L., Li, G., and Hao, L. (2013). Reducing basal salicylic acid enhances Arabidopsis tolerance to lead or cadmium. Plant Soil 372, 309-318. doi: 10.1007/s11104-013-1749-2

Valentovičová, K., Halušková, L., Huttová, J., Mistrík, I., and Tamás, L. (2010). Effect of cadmium on diaphorase activity and nitric oxide production in barley root tips. J. Plant Physiol. 167, 10-14. doi: 10.1016/j.jplph.2009.06.018

Vestena, S., Cambraia, J., Ribeiro, C., Oliveira, J. A., and Oliva, M. A. (2011). Cadmium induced oxidative stress and antioxidative enzyme response in Water Hyacinth and Salvinia. Braz. J. Plant Physiol. 23, 131-139. doi: 10.1590/S167704202011000200005

Wang, Q., Liang, X., Dong, Y., Xu, L., Zhang, X., Kong, J., et al. (2013). Effects of exogenous salicylic acid and nitric oxide on physiological characteristics of perennial ryegrass under cadmium stress. J. Plant Growth Regul. 32, 721-731. doi: 10.1007/s00344-013-9339-3

Wang, Y., Gao, C., Liang, Y., Wang, C., Yang, C., and Liu, G. (2010). A novel bZIP gene from Tamarix hispida mediates physiological responses to salt stress in tobacco plants. J. Plant Physiol. 167, 222-230. doi: 10.1016/j.jplph.2009.09.008

Wen, X. P., Ban, Y., Inoue, H., Matsuda, N., Kita, M., and Moriguchi, T. (2011) Antisense inhibition of a spermidine synthase gene highlights the role of polyamines for stress alleviation in pear shoots subjected to salinity and cadmium. Environ. Exp. Bot. 72, 157-166. doi: 10.1016/j.envexpbot.2011.03.001

Wrzaczek, M., Brosché, M., and Kangasjärvi, J. (2013). ROS signaling loops production, perception, regulation. Curr. Opin. Plant Biol. 16, 575-582. doi: 10.1016/i.pbi.2013.07.002

Xiong, J., Fu, G., Tao, L., and Zhu, C. (2010). Roles of nitric oxide in alleviating heavy metal toxicity in plants. Arch. Biochem. Biophys. 497, 13-20. doi: 10.1016/j.abb.2010.02.014

Xiong, J., Lu, H., Lu, K., Duan, Y., An, L., and Zhu, C. (2009). Cadmium decreases crown root number by decreasing endogenous nitric oxide, which is indispensable for crown root primordia initiation in rice seedlings. Planta 230, 599-610. doi: 10.1007/s00425-009-0970-y

Xu, J., Wang, W., Sun, J., Zhang, Y., Ge, Q., Du, L., et al. (2011). Involvement of auxin and nitric oxide in plant Cd-stress responses. Plant Soil 346, 107-119. doi: 10.1007/s11104-011-0800-4 
Xu, J., Wang, W., Yin, H., Liu, X., Sun, H., and Mi, Q. (2010). Exogenous nitric oxide improves antioxidative capacity and reduces auxin degradation in roots of Medicago truncatula seedlings under cadmium stress. Plant Soil 326, 321-330. doi: 10.1007/s11104-009-0011-4

Yakimova, E. T., Kapchina-Toteva, V. M., Laarhoven, L. J., Harren, F. M., and Woltering, E. J. (2006). Involvement of ethylene and lipid signalling in cadmium-induced programmed cell death in tomato suspension cells. Plant Physiol. Biochem. 44, 581-589. doi: 10.1016/j.plaphy.2006.09.003

Yamaguchi, H., Fukuoka, H., Arao, T., Ohyama, A., Nunome, T., Miyatake, K., et al. (2010). Gene expression analysis in cadmium-stressed roots of a low cadmiumaccumulating solanaceous plant, Solanum torvum. J. Exp. Bot. 61, 423-437. doi: 10.1093/jxb/erp313

Yanez Barrientos, E., Wrobel, K., Lopez Torres, A., Gutiérrez Corona, F., and Wrobel, K. (2013). Application of reversed-phase high-performance liquid chromatography with fluorimetric detection for simultaneous assessment of global DNA and total RNA methylation in Lepidium sativum: effect of plant exposure to $\mathrm{Cd}(\mathrm{II})$ and $\mathrm{Se}(\mathrm{IV})$. Anal. Bioanal. Chem. 405, 2397-2404. doi: 10.1007/s00216-013-6703-x

Yang, H., Shi, G., Wang, H., and Xu, Q. (2010). Involvement of polyamines in adaptation of Potamogeton crispus L. to cadmium stress. Aquat. Toxicol. 100, 282-288. doi: 10.1016/j.aquatox.2010.07.026

Yang, H. Y., Shi, G. X., Li, W. L., and Wu, W. L. (2013). Exogenous spermidine enhances Hydrocharis dubia cadmium tolerance. Russ. J. Plant Physiol. 60, 770-775. doi: 10.1134/S1021443713060162

Yang, J. L., Liu, L. W., Gong, Y. Q., Huang, D. Q., Wang, F., and He, L. L. (2007). Analysis of genomic DNA methylation level in radish under cadmium stress by methylation-sensitive amplified polymorphism technique. J. Plant Physiol. Mol. Biol. 33, 219-226.

Yanhui, C., Xiaoyuan, Y., Kun, H., Meihua, L., Jigang, L., Zhaofeng, G., et al. (2006). The MYB transcription factor superfamily of Arabidopsis: expression analysis and phylogenetic comparison with the rice MYB family. Plant Mol. Biol. 60, 107-124. doi: 10.1007/s11103-005-2910-y

Ye, Y., Li, Z., and Xing, D. (2013). Nitric oxide promotes MPK6-mediated caspase3-like activation in cadmium-induced Arabidopsis thaliana programmed cell death. Plant Cell Environ. 36, 1-15. doi: 10.1111/j.1365-3040.2012.02543.x

Yeh, C. M., Chien, P. S., and Huang, H. J. (2007). Distinct signalling pathways for induction of MAP kinase activities by cadmium and copper in rice roots. J. Exp. Bot. 58, 659-671. doi: 10.1093/jxb/erl240

Yeh, C. M., Hsiao, L. J., and Huang, H. J. (2004). Cadmium activates a mitogenactivated protein kinase gene and MBP kinases in rice. Plant Cell Physiol. 45, 1306-1312. doi: 10.1093/pcp/pch135

Yuan, H. M., Liu, W. C., Jin, Y., and Lu, Y. T. (2013). Role of ROS and auxin in plant response to metal-mediated stress. Plant Signal. Behav. 8, e24671.24671e24671.24673. doi: 10.4161/psb.24671

Zawoznik, M. S., Groppa, M. D., Tomaro, M. L., and Benavides, M. P. (2007). Endogenous salicylic acid potentiates cadmium-induced oxidative stress in Arabidopsis thaliana. Plant Sci. 173, 190-197. doi: 10.1016/j.plantsci.2007.05.004
Zhang, F., Zhang, H., Xia, Y., Wang, G., Xu, L., and Shen, Z. (2011). Exogenous application of salicylic acid alleviates cadmium toxicity and reduces hydrogen peroxide accumulation in root apoplasts of Phaseolus aureus and Vicia sativa. Plant Cell Rep. 30, 1475-1483. doi: 10.1007/s00299-011-1056-4

Zhang, L. W., Song, J. B., Shu, X. X., Zhang, Y., and Yang, Z. M. (2013). MiR395 is involved in detoxification of cadmium in Brassica napus. J. Hazard. Mater. 250-251, 204-211. doi: 10.1016/j.jhazmat.2013.01.053

Zhao, F. Y., Han, M. M., Zhang, S. Y., Wang, K., Zhang, C. R., Liu, T., et al. (2012). Hydrogen peroxide-mediated growth of the root system occurs via auxin signaling modification and variations in the expression of cell-cycle genes in rice seedlings exposed to cadmium stress. J. Integr. Plant Biol. 54, 991-1006. doi: 10.1111/j.1744-7909.2012.01170.x

Zhao, F. Y., Hu, F., Han, M. M., Zhang, S. Y., and Liu, W. (2011). Superoxide radical and auxin are implicated in redistribution of root growth and the expression of auxin and cell-cycle genes in cadmium-stressed rice. Russ. J. Plant Physiol. 58, 851-863. doi: 10.1134/S102144371105027X

Zhao, F. Y., Hu, F., Zhang, S. Y., Wang, K., Zhang, C. R., and Liu, T. (2013). MAPKs regulate root growth by influencing auxin signaling and cell cycle-related gene expression in cadmium-stressed rice. Environ. Sci. Pollut. Res. Int. 20, 5449-5460. doi: 10.1007/s11356-0131559-3

Zhou, Z. S., Song, J. B., and Yang, Z. M. (2012). Genome-wide identification of Brassica napus microRNAs and their targets in response to cadmium. J. Exp. Bot. 63, 4597-4613. doi: 10.1093/jxb/ers136

Zhu, X. F., Wang, Z. W., Dong, F., Lei, G. J., Shi, Y. Z., Li, G. X., et al. (2013). Exogenous auxin alleviates cadmium toxicity in Arabidopsis thaliana by stimulating synthesis of hemicellulose 1 and increasing the cadmium fixation capacity of root cell walls. J. Hazard. Mater. 263, 398-403. doi: 10.1016/j.jhazmat.2013.09.018

Conflict of Interest Statement: The authors declare that the research was conducted in the absence of any commercial or financial relationships that could be construed as a potential conflict of interest.

Received: 03 March 2014; paper pending published: 18 April 2014; accepted: 14 May 2014; published online: 03 June 2014.

Citation: Chmielowska-BąkJ, Gzyl J, Rucińska-Sobkowiak R, Arasimowicz-Jelonek M and Deckert J (2014) The new insights into cadmium sensing. Front. Plant Sci. 5:245. doi: $10.3389 / \mathrm{fpls} .2014 .00245$

This article was submitted to Plant Physiology, a section of the journal Frontiers in Plant Science.

Copyright (C) 2014 Chmielowska-Bąk, Gzyl, Rucinska-Sobkowiak, ArasimowiczJelonek and Deckert. This is an open-access article distributed under the terms of the Creative Commons Attribution License (CC BY). The use, distribution or reproduction in other forums is permitted, provided the original author(s) or licensor are credited and that the original publication in this journal is cited, in accordance with accepted academic practice. No use, distribution or reproduction is permitted which does not comply with these terms. 